\title{
Phytochemical, Proximate Analysis, Vitamin and Mineral Composition of Aqueous Extract of Ficus capensis leaves in South Eastern Nigeria
}

\author{
Ngozi Kalu Achi ${ }^{1}$, Chimaraoke Onyeabo ${ }^{1}$, Chima Agatha Ekeleme-Egedigwe ${ }^{2 *}$, Jennifer Chituru Onyeanula ${ }^{1}$ \\ ${ }^{1}$ Michael Okpara University of Agriculture, Umudike, PMB 7267, Umuahia, Abia State, Nigeria. \\ ${ }^{2}$ Federal University Ndufu- Alike, Ikwo, PMB 1010 Abakaliki, Ebonyi State, Nigeria.
}

\begin{tabular}{|c|c|}
\hline ARTICLE INFO & ABSTRACT \\
\hline Article history: & \multirow{12}{*}{$\begin{array}{l}\text { The phytochemical, proximate, vitamin and mineral composition of the aqueous extract of the leaves of Ficus } \\
\text { capensis collected from Ikwuano Local Government Area (LGA) in Abia State was investigated. The } \\
\text { parameters investigated were determined using standard biochemical methods. Phytochemical studies carried } \\
\text { out on aqueous extract of Ficus capensis leaves showed high levels of flavonoids, terpenoids, tannins and } \\
\text { alkaloids while glycosides, saponins, steroids were in trace amount. The proximate analysis of the leaves } \\
\text { revealed that Ficus capensis leaves is a poor source of lipid }(1.83 \%) \text { and fiber }(4.77 \%) \text { but has very high } \\
\text { moisture content }(104.53 \%) \text { and carbohydrate }(73.77 \%) \text {, moderate amount of ash }(6.65 \%) \text { and protein }(6.31 \%) \text {. } \\
\text { This composition shows that the sample could be a good source of carbohydrate and moisture. The result also } \\
\text { showed that the leaves contain a variety of vitamins (A, B-complex, C , E, D, K and carotenoid) with } \beta \text { - } \\
\text { carotenoid ( } 6.55 \pm 0.009 \%) \text { having the highest concentration and Vitamin A ( } 6.06 \pm 0.004) \text { while the B-Vitamins } \\
\text { and Vitamin E are in moderate amount. The mineral content showed the presence of zinc, calcium, magnesium, } \\
\text { phosphorus, potassium and iron content. This indicates the tendency of Ficus capensis to be able to control } \\
\text { osmotic balance, essential for bone formation, lower blood pressure and also act a source of antioxidant vitamins } \\
\text { and minerals. The presence of these phytochemicals, minerals and vitamins in this leafy vegetable supports the } \\
\text { use of the leaves of Ficus capensis both for food and ethno medicine purposes in many parts of Nigeria. }\end{array}$} \\
\hline Received on: $01 / 10 / 2016$ & \\
\hline Accepted on: $26 / 11 / 2016$ & \\
\hline Available online: $30 / 03 / 2017$ & \\
\hline Key words: & \\
\hline Ficus capensis, & \\
\hline Phytochemical, Proximate, & \\
\hline Vitamins, Minerals. & \\
\hline & \\
\hline & \\
\hline & \\
\hline & \\
\hline
\end{tabular}

\section{INTRODUCTION}

The therapeutic use of natural products from indigenous plants for ethnomedicinal and nutritional purposes has grown tremendous interest among scientists to search for bioactive components (Oktay et al., 2003; Wangensteen et al., 2004) that are beneficial to man. Recently, the interest in natural products from plants and their use has increased tremendously even in areas where conventional medicines are very much available. Medicinal plants are sources of raw materials for pharmaceutical drug formulation (WHO, 2014). A significant percentage of medicinal plants used by the rural populace in Africa are

* Corresponding Author

Email: chimaeges@gmail.com affordable when compared to the high cost of conventional drugs. In the rural communities, people depend mostly on traditional medicine which also recognizes their socio-cultural and religious background which orthodox medicine neglects (Adesina, 2014). Medicinal plants contain numerous biologically active compounds such as nutrients and phytochemicals which have physiological actions on the human body (Olowokudejo et al., 2008) and these inherent active ingredients are used to treat various ailments (Okigbo et al., 2008). A majority of the world's population in developing countries still relies on herbal medicines to meet their health needs (Uzoekwe and Mohammed, 2015). Presently, in Nigeria, vegetables are the cheapest and readily available sources of proteins, vitamins and minerals (Thompson and Kelly, 1990) and therefore could also benefit the populace with their medicinal properties. 
Ficus capensis commonly called "bush fig tree" belongs to the family Moraceae. In Nigeria, it is locally referred to as Akokoro (Igbo) Opoto (Yoruba) and Uwaraya (Hausa) (Otitoju et al., 2014). Its leaves are broad, greenish and produce fruits all year round (Arnold and Dewett, 1993) and have been regarded as an underutilized plant. The leaves of Ficus capensis are used as vegetable both in soup and yam pottage in various parts of Nigeria (South East) (Otitoju et al., 2014). Traditionally, Ficus capensis has been used for the treatment of dysentery and wound dressing (Igoli et al., 2005). It is also used to treat circumcision wounds, leprosy and epilepsy, rickets, infertility, gonorrhea, edema and respiratory disorders (Olowokudejo et al., 2008) and abortion (Owolabi et al., 2009). Apart from its traditional uses, scientific investigations have reported its; blood-boosting effect (Otitoju et al., 2014; Njoku-oji et al., 2016), anti-sickling (Umeokoli et al.,2013; Mpiana et al., 2008) antibacterial (Oyeleke et al.,2008), anti-abortifacient (Owolabi et al., 2009), immune-stimulatory (Daikwo et al., 2012), antidiarrhoea (Owolabi, 2013), antioxidant (Ramde-Tiendrebeogo et al., 2012) and pro-fertility in treating azoospermia (Gelfand et al.,1985; Akomolafe et al. ,2016).

To the best of our knowledge, no documented reports on the vitamin and mineral content, nutritive and phytochemical composition of the leaves of this plant harvested from Ikwuano Local Government Area (LGA) in Abia State has been published. In order to ascertain the nutritive value of the vegetable species and thereby stimulate interest in its utilization beyond the traditional localities. Therefore, it is important to validate scientific documentation on the leaves of the plant harvested from Abia State in Nigeria for the presence of essential minerals, vitamins, phytochemical and proximate composition so as to promote and scientifically validate its health and ethnomedicinal benefit.

\section{MATERIALS AND METHODS}

\section{Collection and preparation of plant extract}

The fresh leaves of Ficus capensis was collected from a local farm in Umudike in Ikwuano Local Government Area of Abia State. The leaves were identified in the Department of Forestry and Environmental Management in Michael Okpara University of Agriculture Umudike in Abia State. The leaves were air dried at room temperature to a constant weight. The dried leaves were then pulverized to powder using an electric grinding machine (Panasonic MX-337N). The powdered material was stored in air-tight containers. Five hundred grams $(500 \mathrm{~g})$ of the powdered leaf sample was extracted using $1500 \mathrm{ml}$ of distilled water for $48 \mathrm{hrs}$ with continuous stirring. The mixture was filtered using Whatman paper No1. The filtrate was evaporated to dryness using a water bath to obtain $30 \%$ yield.

\section{Phytochemical analyses}

Alkaloids, glycoside, terpenoids were determined using the method described by Harborne, (1973). The alkaline picrate method was employed for the determination of cyanogenic glycosides (Onwuka, 2005). The percentage composition of tannins and steroids in the plants was determined with some modifications while saponin content was determined using the method of AOAC (1990). Determination of flavonoid content was done by the method described by Bohnr and Kocipai (1994).

\section{Proximate Analyses}

The parameters determined for proximate analyses include ash, moisture, crude protein, fat, fiber and carbohydrate. All of these were carried out using the methods described by (AOAC, 2010).

\section{Vitamin composition}

The amount of vitamin A, E, C, B ${ }_{12}$ in the sample was determined using the method described by (Achikanu et al, 2013; AOAC, 2010.) Vitamin $B_{1}$ and $B_{3}$ were determined using the method described by Okwu and Ndu, (2006) while Vitamin $\mathrm{B}_{2}, \mathrm{~K}$, folate were determined using the methods described by Okwu and Josiah (2006). The method described by Oulai et al (2014) was used in the determination of $\beta$-carotene..

\section{Mineral Analyses}

The atomic absorption spectrophotometer (AAS) was used for the analyses of the following metals: $\mathrm{Mg}, \mathrm{Zn}, \mathrm{Fe}, \mathrm{Cd}, \mathrm{Cu}$, $\mathrm{Pb}, \mathrm{Ca}, \mathrm{Ni}$, and $\mathrm{P}$ while the flame photometer was used in the analyses of $\mathrm{K}$ and $\mathrm{Na}$. Using AAS, the ash solutions of the plant samples were prepared by weighing $5 \mathrm{~g}$ of each of the powdered plant samples, these were ashed at $550^{\circ} \mathrm{C}$ in muffle furnace for 5 hrs, and the residues dissolved in $100 \mathrm{ml}$ of deionized water. Suitable salts of the metals were used to make their standards, lamps were fixed. The standard minerals solutions were injected to calibrate the AAS using acetylene gas. An aliquot of ash solutions were injected and the concentrations obtained from the AAS. Using the flame photometer, the diluents of sample was aspirated into the Jenway Digital flame photometer using the filter corresponding to each mineral element. All of these were carried out using the method described by (Oshodi, 1992).

\section{Statistical Analysis}

Data was analyzed using SPSS Version 20.0. Results were expressed as Mean \pm SD of three replicates determinations.

\section{RESULTS AND DISCUSSION}

Table 1 shows the quantitative phytochemical analysis of Ficus capensis leaves. The leaves contain copious presence of flavonoids (1367.42 \pm 0.005), terpenoids (1280.39 \pm 0.003$)$, tannins (687.64 \pm 0.006), alkaloids (422.12 \pm 0.006) while saponins $(0.27 \pm 0.004)$, steroids $(0.476 \pm 0.004)$, glycosides $(11.39 \pm 0.003)$ and hydrogen cyanide $(0.55 \pm 0.008)$ are in trace amount respectively. The presence of tannins $(687.64 \mathrm{mg} / 100 \mathrm{~g})$ in the leaves of Ficus capensis confers the leaves to be a good source for the treatment of wounds emanating from varicose ulcers and hemorrhoids (Njoku and Akumufula, 2007). Plants that contain 
tannins are used as astringents, against diarrhea, as diuretics, against stomach and duodenal tumours (Saxena et al., 2013). Flavonoids in plants possess medicinal benefits which includes antioxidant and anti-inflammatory activities (Saxena et al., 2012). They have the ability to scavenge hydroxyl radicals, super oxide anions and lipid peroxy radicals (Okwu, 2004; Okwu and Josiah, 2006), therefore supports its antioxidant activity. The flavonoid content of the leaves of Ficus capensis therefore supports its use for protection against diseases such as cancer, inflammation and atherosclerosis (Onyeka and Nwambekwe, 2007).

Table 1: Phytochemical composition of Ficus capensis leaves.

\begin{tabular}{cc}
\hline Phytochemical constituent & Value \\
\hline Flavonoids $(\mathrm{mg} / 100 \mathrm{~g})$ & $1367.42 \pm 0.005$ \\
Alkaloids $(\mathrm{mg} / 100 \mathrm{~g})$ & $422.12 \pm 0.006$ \\
Saponins $(\mathrm{mg} / 100 \mathrm{~g})$ & $0.27 \pm 0.004$ \\
Steroids $(\mathrm{mg} / 100 \mathrm{~g})$ & $0.48 \pm 0.004$ \\
Glycosides $(\mathrm{mg} / 100 \mathrm{~g})$ & $11.39 \pm 0.003$ \\
Terpenoids $(\mathrm{mg} / 100 \mathrm{~g})$ & $1280.39 \pm 0.003$ \\
Tannins $(\mathrm{mg} / 100 \mathrm{~g})$ & $687.64+0.006$ \\
Hydrogen cyanide $(\mathrm{mg} / \mathrm{lg})$ & $0.55 \pm 0.008$
\end{tabular}

Results are expressed as Mean \pm Standard deviation (SD).

The presence of alkaloids $(422.12 \mathrm{mg} / 100 \mathrm{~g})$ in the leaves of Ficus capensis supports the findings by Oyeleke et al., (2008), that the antibacterial activity of this plant may be attributed to the presence of alkaloids. Alkaloids have been reported to possess various pharmacological activities including antihypertensive effects, antiarrhythmic effect, antimalarial and anticancer activity (Saxena et al., 2013). Pure isolated alkaloids and their synthetic compounds have been used in medicine as an analgesic, antispasmodic and bactericidal agents (Stary, 1998; Okwu, 2004). Saponins from fruits and vegetables are important dietary supplements and are known to exhibit antimicrobial activities and protect plants from microbial pathogens (Sczkowski et al., 1988). They could be beneficial in modulating blood lipids, lower cancer risks and improve blood glucose response as well as possess antioxidant activity (Igidi and Edene, 2014). Leafy vegetables such as Ficus capensis leaves are thus said to possess antimicrobial property attributed to saponins and other phytochemicals present. This is in agreement with reports on the antimicrobial potentials of Ficus capensis obtained from other localities in Nigeria (Ogundare and Akinyemi, 2013; Igwe et al., 2016).

The presence of terpenoids in the leaves of Ficus capensis supports its use in the treatment and management of cancer, ulcers and malaria. Plants produce volatile terpenes either to attract specific insects for pollination or otherwise to expel certain preys which consume these plants as food (Degenhardt et al, 2003). In addition, terpenoids possess medicinal properties such as anticarcinogenic, antimalarial, anti-ulcer, antimicrobial or diuretic activity (Dudareva et al, 2004). So therefore, leaves of Ficus capensis could be used in ethnomedicine in the management of various ailments due to the presence of these terpenes.

The value obtained for hydrogen cyanide (HCN) in Ficus capensis leaves is $0.55 \mathrm{mg} / \mathrm{g}$ and is less than the $36 \mathrm{mg} / 100 \mathrm{~g}$ considered lethal dose for man (Mgbagwu, et al 2010). Thus, its leaves can be said to be safe both for human and animal consumption as its $\mathrm{HCN}$ levels is within permissible limits. HCN is a poisonous chemical asphyxiant, which stops the tissue from utilizing oxygen (Brown et al., 2001). Processing methods such as boiling and soaking of vegetables for a period of time can significantly reduce the HCN levels (Siddhuraju, et al, 1996).

Plant extracts containing cyanogenic glycosides could be used as flavoring agents in pharmaceutical preparations (Sarker and Nahar, 2007). Therefore, the presence of glycoside $(11.39 \mathrm{mg} / 100 \mathrm{~g})$ in the leaves of Ficus capensis supports its pharmacological use as a flavouring agent and in the management of cancer. This report contradicts reports by Oyeleke et al., (2008) which reported that its leaves contain no glycosides. Plant steroids are phytoconstituents that have found therapeutic applications as arrow poisons or cardiac drugs (Firn, 2010). Trace amounts of steroid content $(0.48 \mathrm{mg} / 100 \mathrm{~g})$ in the leaves could be useful in promoting nitrogen retention in osteoporosis and in animals with wasting illness (Maurya et al., 2008; Madziga et al., 2010). The proximate compositions determined in the plant leaves are summarized in table 2 .

Table 2: Proximate composition of Ficus capensis leaves.

\begin{tabular}{cc}
\hline Components & Value (\%) \\
\hline Moisture & $104.53 \pm 0.003$ \\
Ash & $6.65 \pm 0.004$ \\
Fat & $1.83 \pm 0.004$ \\
Proteins & $6.31 \pm 0.007$ \\
Fiber & $4.77 \pm 0.007$ \\
Carbohydrate & $73.77 \pm 0.002$ \\
\hline
\end{tabular}

Results are expressed as Mean \pm Standard deviation.

It shows that the plant has a high moisture content $(104.53 \pm 0.003)$ and carbohydrate $(73.77 \pm 0.002)$, moderate concentration of protein $(6.31 \pm 0.007)$ and ash $(6.65 \pm 0.004)$, and low concentration of fat $(1.83 \pm 0.004)$ and fiber $(4.77 \pm 0.007)$. The moisture content $(104.53 \%)$ of the leaves shows that plant is a good source of water from vegetables for the cells of the body (Okeke et al, 2008). The estimated carbohydrate content in the leaves of Ficus capensis (73.77) was high and carbohydrates are known to produce energy required for the body because they are essential nutrient required for adequate diet (Emebu and Anyika, 2011) and supplies energy to cells such as brain, muscle and blood (Ejelonu et al., 2011). The low content of fat $(1.83 \mathrm{mg} / 100 \mathrm{~g})$ is below the range $(8.3 \%-27.0 \%)$ reported for some leafy vegetables consumed in Nigeria (Sena et al., 1998). Leafy vegetables are poor sources of lipids (Ifon and Bassir, 1980; Ejoh et al., 1996), therefore the increase in the consumption of vegetables would naturally lower fat intake. The protein content of the leaves was found to be moderately available $(6.31 \%)$. Protein is vital for various body functions such as body development, maintenance of fluid balance, formation of hormones, enzymes and sustaining strong immune function (Emebu and Anyika, 2011). Fresh green leafy vegetables with low protein content have been reported (Ifon and Bashir, 1989; Oboh and Masodje, 2009) and the protein in these leaves are in the form of enzymes, instead of being a storage pool as found in grains and nuts (Wills et al., 1998). Crude fiber 
content of this plant could aid in the absorption of trace elements in the gut and therefore increases intestinal bowel movement (Abolaji et al., 2007). Consuming vegetables in our diet could aid in managing constipation problems (Olowokudejo et al., 2008). Dietary fibers also lower cholesterol, triglycerides and protect against cancer and digestive disorders (Selvendran, 1984). The moderate amount of ash content in the leaves of Ficus capensis provides a measure of total amount of mineral matter in a plant. Measuring ash content is important because mineral matter may be the cause of a pharmacological effect (Okeke, 1998).

Table 3: Vitamin content of Ficus capensis leaves.

\begin{tabular}{|c|c|}
\hline Components & Concentration \\
\hline Vitamin E (mg/100g) & $0.35 \pm 0.004$ \\
\hline Vitamin C (mg/100g) & $0.26 \pm 0.002$ \\
\hline Vitamin A $(\mu \mathrm{g})$ & $6.06 \pm 0.004$ \\
\hline Vitamin $B_{1}(\mathrm{mg} / 100 \mathrm{~g})$ & $0.46 \pm 0.003$ \\
\hline Vitamin $B_{2}(\mathrm{mg} / 100 \mathrm{~g})$ & $0.68 \pm 0.002$ \\
\hline Vitamin $B_{3}(\mathrm{mg} / 100 \mathrm{~g})$ & $0.36 \pm 0.003$ \\
\hline Vitamin $B_{6}(\mathrm{mg} / 100 \mathrm{~g})$ & $0.29 \pm 0.006$ \\
\hline Vitamin $B_{7}(\mathrm{mg} / 100 \mathrm{~g})$ & $0.15 \pm 0.005$ \\
\hline Vitamin $\mathrm{B}_{9}(\mathrm{mg} / 100 \mathrm{~g})$ & $0.24 \pm 0.005$ \\
\hline Vitamin D (mg/100g) & $0.13 \pm 0.005$ \\
\hline Vitamin $B_{12}(\mathrm{mg} / 100 \mathrm{~g})$ & $0.37 \pm 0.003$ \\
\hline Vitamin K (mg/100g) & $0.14 \pm 0.003$ \\
\hline Carotenoid (mg/100g) & $6.55 \pm 0.009$ \\
\hline
\end{tabular}

Results are expressed as Mean \pm Standard Deviation of three replicates values

The result in table 3 shows the presence of carotenoid and Vitamin A while the B-Vitamins, Vitamin E, Vitamin C are in moderate amounts. Although vitamins $\mathrm{C}$, vitamin $\mathrm{E}$, niacin $\left(\mathrm{B}_{3}\right)$, thiamine $\left(B_{1}\right)$, riboflavin $\left(B_{2}\right)$, pyridoxine $\left(B_{6}\right)$, biotin $\left(B_{7}\right)$, folic acid $\left(B_{9}\right)$, vitamin $B_{12}$, vitamin $D$ and vitamin $K$ were in trace amount in the leaves, they have very essential roles to play in the human health. Vitamin $\mathrm{C}$ and $\mathrm{E}$ are very important antioxidants which protect the cell membranes from oxidative stress/damage caused by free radicals (Guyton and Hall, 2006). Ficus capensis leaves contain ascorbic acid and flavonoids, both of which are effective antioxidants. Vitamin $\mathrm{C}$ possesses an antioxidant property and required for maintenance of normal connective tissues, wound healing and also facilitates the absorption of dietary iron from the intestine (Button, 2004).

This justifies the antioxidant activity of the leaves as reported by Oyeleke et al., (2008). Deficiencies of these vitamins predispose the red cell membranes to damage leading to haemolysis (Adesina, 2006). Riboflavin and niacin are necessary for oxidative phosphorylation and for coenzyme formation respectively (Adesina, 2006). The leaves of Ficus capensis contains moderate amount of vitamin A and therefore essential for clear vision.

The mineral compositions of Ficus capensis leaves are shown in table 4 . It contains considerable amount of Zinc (2.84 \pm $0.005)$, Iron (1.89 \pm 0.004$)$, Calcium (1.86 \pm 0.003$)$, Magnesium $(1.92 \pm 0.004)$ and Potassium $(0.72 \pm 0.006)$. Pathak and Kapil, (2004) reported that zinc is vital in protein synthesis, cellular differentiation and replication, immunity and sexual functions. Calcium is reported to be essential for blood clotting, bone and teeth formation and as a co-factor in some enzyme catalysis (Robert et al., 2003). In humans, magnesium is required in the plasma and extracellular fluid, where it helps maintain osmotic equilibrium (Thomas and Krishnakumari, 2015).

It can also prevent some heart disorders and lower blood pressure in humans. Iron facilitates the oxidation of biomolecules to control obesity, which predisposes an individual to various diseases. It is also essential for hemoglobin formation (Thomas and Krishnakumari, 2015) and plays a role in energy transfer within the plant and also an essential constituent of certain enzymes and proteins. This justifies the use of Ficus capensis in folklore medicine as a blood tonic because of its blood boosting effect (Njoku-oji et al., 2016).

Moderate quantities of sodium and potassium were present in the leaves of Ficus capensis and these are principal cations of extracellular and intra-cellular fluids and aid in maintaining electrolyte balance in the body (Robert et al., 2003). Potassium is essential and is required in large amounts for proper growth and plant reproduction. Phosphorous maintain blood sugar levels and normal heart contraction (Linder, 1991).

It is also important for normal cell growth and repair, bone growth and kidney function. It plays an important role in maintaining the body's acid-alkaline balance (Johns and Duquette, 1991). Minerals found to be present in trace quantities are cadmium, nickel and lead. Cadmium and lead in high amounts are not ideal and not desirable for the functioning of the body. The research forms a basis for further isolation and characterization on the bioactive constituents present in the leaves of this plant due to its therapeutic properties.

Table 4: Mineral content of Ficus capensis leaves.

\begin{tabular}{cc}
\hline Table 4: Mineral content of Ficus capensis leaves. \\
\hline Mineral components & Concentration \\
\hline Sodium $(\%)$ & $0.17 \pm 0.004$ \\
Zinc $(\mathrm{mg} / 100 \mathrm{~g})$ & $2.84 \pm 0.005$ \\
Lead $(\mathrm{mg} / \mathrm{kg})$ & $0.03 \pm 0.003$ \\
Copper $(\mathrm{mg} / \mathrm{kg})$ & $0.34 \pm 0.003$ \\
Cadmium $(\mathrm{mg} / \mathrm{kg})$ & $0.14 \pm 0.002$ \\
Nickel $(\mathrm{mg} / \mathrm{kg})$ & $0.01 \pm 0.003$ \\
Iron $(\mathrm{mg} / 100 \mathrm{~g})$ & $1.89 \pm 0.04$ \\
Phosphorus $(\mathrm{mg} / 100 \mathrm{~g})$ & $0.16 \pm 0.004$ \\
Calcium $(\%)$ & $1.86 \pm 0.003$ \\
Magnesium $(\%)$ & $1.92 \pm 0.004$ \\
Potassium $(\%)$ & $0.72 \pm 0.006$
\end{tabular}

Results are expressed as Mean \pm Standard Deviation.

\section{CONCLUSION}

The present study shows the presence of phytochemicals, vitamins, minerals and nutrients in Ficus capensis leaves which may therefore justify both its nutritional and ethnomedicinal benefits to human health. The study further revealed low level of toxicants such as glycosides and hydrogen cyanide, with high levels of flavonoid, tannin, alkaloid. The leaves also showed a high level of moisture and carbohydrate. Leaves of Ficus capensis seem to have good nutritive, vitamin and suitable mineral element value necessary to maintain good health. 


\section{AUTHOR'S CONTRIBUTION}

This work was carried out in collaboration among all authors. Authors ANK and OC designed the study, wrote the protocol and wrote the first draft of the manuscript. Author EAC managed the literature searches, statistical analyses of the study and editing of the manuscript. OJC managed the literature searches and the experimental process. All authors read and approved the final manuscript.

\section{DECLARATION OF CONFLICTING INTERESTS}

The author(s) declared no potential conflicts of interest with respect to the research, authorship, and/or publication of this article.

\section{REFERENCES}

Abolaji OA, Adebayo AH, Odesanmi OS. Nutritional qualities of three medicinal plant parts (Xylopia aethiopica, Blighia sapida and Parinari polyandra) commonly used by pregnant women in the Western Part of Nigeria. Pakistan Journal of Nutrition, 2007; 6 (6): 665-668.

Achikanu CE, Eze-Steven PE, Ude CM, Ugwuokolie OC. Determination of the vitamin and mineral composition of common leafy vegetables in South Eastern Nigeria. International Journal of Current Microbiology and Applied Sciences, 2013; 2 (11): 347-353.

Adesina, SK. Studies of some plants used as anticonvulsants in American and African traditional medicine. London, 2006; 42 (8): 48-59.

Adesina, SK. Traditional Medical Care in Nigeria. Online Nigeria Daily News [Online], 2014; 50(6) available at online daily Nigeria daily news http:// www. Onlinenigeria.com/health/[accessed 19 August, 2016].

Akomolafe SF, Oboh G, Oyeleye SI, Boligon AA. Aqueous extract from Ficus capensis leaves inhibits key enzymes linked to erectile dysfunction and prevent oxidative stress in rats' penile tissue. NFS Journal, 2016; 4: 15-21.

Arnold TH, Dewett BC. Plants of southern Africa: names and distribution. Mem. Bot. Surv. S. Africa; 1993; 62: 23 - 27.

AOAC. Association of Official Analytical Chemists Method of Analysis; 15th edition, Washington D.C.1990; 222-236.

AOAC. Minerals: In Official Methods of analysis, Washington, DC: Association of Official Analytical Chemists. 2010; 16(3): 99 - 103

Bohnr MK, Kocipai A. Flavonoids Composition and Uses. Smith Sonian Inst. Press, Washington, D. C. 1994; $106-109$.

Brown TL, Le May HE, Buoxten BE, Murphy CJ. Chemistry, The central science. 11th Edn. Pearson International. 2001; 162-163 \& pp 960- 961

Button KC. Prescription for nutritional healing. Penguin Putnam, 2004; 4(5): 478- 479

Daikwo OA, Tende JA, Okey SM, Eze ED, Isa AS. The effect of aqueous extract of leaf of Ficus capensis Thunb (Moraceae) on invivo leukocyte mobilization in Wistar rats. British Journal of Pharmacology and Toxicology, 2012; 3(3):110-114.

Degenhardt J, Gershenzon J, Baldwin IT, Kessler A. Attracting friends to feast on foes: Engineering terpene emission to make crop plants more attractive to herbivore enemies. Current Opinion Biotechnology; 2003; 14: 169-176.

Dudareva N, Pichersky E, Gershenzon J. Biochemistry of plant volatiles. Plant Physiology; 2004; 135: 1893-1902.

Ejelonu BC, Lasisi AA, Olaremu AG, Ejelonu OC. The chemical constituents of calabash (Crescentia cujete). African Journal of Biotechnology, 2011; 10(84): 19631-19636.

Ejoh, RA. Tchouanguep MF, Fokou E. Nutrient compostion of the leaves and flower of Colocassia esculenta and the fruits of Solanum melongena. Plant Food Human Nutrition, 1996; 49: 107-112.
Emebu PK, Anyika JU. Proximate and mineral composition of Kale (Brassica oleracea) grown in Delta State, Nigeria. Pakistan Journal of Nutrition, 2011; 10(2): 190 - 194.

Firn R. Nature's Chemicals. Oxford University Press, Oxford. $2010 ; 74-75$

Gelfand M, Mavi S, Drummond RB, Ndemera B. The traditional medicinal practitioner in Zimbabwe. Mambo Press, Gweru, Zimbabwe. 1985; 411.

Guyton C, Hall JE. Textbook of medical physiology. Elseveir publisher, Philadelphia, India; 2006; 11: 113-115.

Harborne JB. Phytochemical Methods: A guide to modern techniques of plant analysis. Chapman and Hall, New York. 1973; 2: 88185 .

Ifon ET, Bassir O. The nutritive value of some Nigeria leafy vegetable Part 2: the distribution of protein, carbohydrates including ethanol, soluble simple sugars, crude fat, fibre and ash. Food Chemistry, $1980 ; 5: 231-235$.

Ifon ET, Bassir, O. The nutritive value of some Nigeria leafy green vegetable Part 1: vitamin and mineral contents. Food Chemistry, 1989; 4: 263-267.

Igidi OJ, Edene CE. Proximate and phytochemical compositions of Napoleona vogelii hook fruit. The International Journal of Engineering and Science, 2014; 3(6): 46-51

Igoli JO, Ogaji OG, Tor-Aryiin A, Igoli, NP. Traditional Medicinal Practices amongst the Igede people of Nigeria. Part 11. African Journal of Tradition. Complement. 2005; 2(2):134-152.

Igwe KK, Udeh NE, Madubuike AJ, Amuneke CC. Characterization and antimicrobial studies of Ficus capensis methanolic leaf extract. International Journal of Advanced Research in Science, Engineering and Technology, 2016; 3(4):1931-1941.

Johns T, Duquette M. Deficiency of phosphorus in man. Am. J. of Clin. Nutr., 1991; 53: 448 - 56. 46.

Linder MC. Nutritional Biochemistry and metabolism with clinical applications. Appleton and Lange, Norwalk, 1991; 2: 191 - 212

Madziga HA, Sanni S, Sandabe UK. Phytochemical and elemental analysis of Acalypha wilkesiana leaf. Journal of American Science, 2010; 6(11): 510-514.

Maurya R, Singh G, Yadav PP. Anti osteoporotic agents from Natural sources. In: Atta-ur-Rahman. Studies in Natural Products Chemistry, Elsevier. 2008; 35: 517-545.

Mgbagwu FN, Chuba C, Unamba CI, Nwosu IC. Proximate Analysis and Mineral Composition of Seeds of Treculia africana and Artocarpulus atiti (Mora Leae); International Science Research Journal, 2010; 2: $121-123$

Mpiana PT, Mudogo V, Tshibangu DST, Kitwa EK, Kanangila AB, Lumbu JBS, Ngbolua KN, Atibu EK, Kakule MK. Antisickling activity of anthocyanins from Bombax pentadrum, Ficus capensis, Zizyphus mucronata: Photo degradation effect. J. Ethnopharmacol. 2008; 120: 413-418.

Njoku PC, Akumufula MI. Phytochemical and nutrient evaluation of Spondias mombin leaves. Pakistani J. Nutr., 2007; 6(6):613615.

Njoku-Oji NN, Nwike CV, Dimkpa U, Ifegwu NO, Anike LC, Maduka SO, Sobanke OA, Uchefuna RC. Hematological changes following oral administration of aqueous leaf extract of Ficus capensis in albino rats. International Blood Research and Reviews, 2016; 5(1): 1-7.

Oboh FOJ, Masodje HI. Nutritional and antimicrobial properties of Vernonia amygdalina leaves. International Journal of Biomedical and Health Sciences, 2009; 5 (2):51-56.

Ogundare AO, Akinyemi AI. Synergetic effect of the leaf extracts of Ficus capensis (Linn) and Sorghum bicolor (Linn) Moench against some human bacterial pathogens. FUTA Journal of Research in Sciences, 2013 (1): 94-100.

Okeke EC. The use and Chemical content of some indigenous Nigerian spices. Journal of Herbs, Spices and Medicinal plants, 1998; 5 : $51-63$.

Okeke, CU, Izundu AI, Uzoechinda E. Phytochemical and proximate study of female pawpaw (Carica papaya Linn.) Caricaceae. 
Journal of Science, Engineering and Technology 2008; 15 (2): 8207 8216.

Okigbo RN, Eme UE, Ogbogu S. Biodiversity and conservation of medicinal and aromatic plants in Africa. Biotechnology and Molecular Biology Revision, 2008; 3(6): 127-134.

Oktay M, Gülçin I, Küfrevioglu OI. Determination of invitro antioxidant activity of fennel (Foeniculum vulgare) seed extracts. Journal of Advanced Scientific Research, 2003; 36: 263 - 271.

Okwu DE, Ndu CU. Evaluation of the phytonutrient, mineral and vitamin content of some varieties of yam (Discorea spp.). International Journal of Molecular Medicine and Advanced Science, 2006; 2(2): 199-203.

Okwu DE. Phytochemical and vitamin content of indigenous spices of South Eastern Nigeria. J. Sustain Agric. Environ., 2004; 6:30-37.

Okwu, DE, Josiah C. Evaluation of the chemical composition of two Nigerian medicinal plants. African Journal of Biotechnology, 2006; 4: 357-361.

Olowokudejo JD, Kadiri AB, Travih VA. An ethnobotanical survey of herbal markets and medicinal Plants in Lagos State of Nigeria. Ethnobotanical Leaflets, 2008; 12: 851-865.

Onyeka EU. Nwambekwe IO. Phytochemical profile of some green leafy vegetables in South East, Nigeria. Nigerian Food Journal, 2007; 25(1), 67-72.

Onwuka GI. Food analysis and instrumentation: theory and practice. Naphtali prints, Nigeria, 2005; 95-96

Oshodi AA. Proximate composition, nutritionally valuable minerals and functional properties of Adenopus breviflorus benth seed flour and protein concentrate. Food Chem., 1992; 45: 79-83.

Otitoju GTO, Nwamarah JU, Otitoju O, Iyeghe LU. Nutrient composition of some lesser known green leafy vegetables in Nsukka L.G.A of Enugu State. Journal of Biodiversity and Environmental Sciences, 2014; 4(4):233-239

Oulai P, Lessoy Z, Rose-Monde M, Ryta Doue, Sébastien, N. Proximate composition and nutritive value of leafy vegetables consumed in northern Côte d'ivoire. European Scientific Journal: 2014; 212-227.

Owolabi OJ. Active ileum relaxant fractions from the leaves of Ficus capensis Thunb (Moraceae). Nigerian Journal of Pharmaceutical Sciences. 2013; 12(1):1-7.

Owolabi OJ, Nworgu ZA, Falodun A, Ayinde BA, Nwako CN. Evaluation of tocolytic activity of ethanol extract of the Stem bark of Ficus capensis Thunb. (Moraceae). Acta Poloniae Pharmaceutica ñ Drug Research. 2009; 66(3):293-296.

Oyeleke SB, Dauda BEN, Boye OA. Antibacterial activity of Ficus capensis. African Journal of Biotechnology. 2008; 7(10):1414-1417.

Pathak P. Kapil U. Role of trace elements zinc, copper and magnesium during pregnancy and its outcome. Indian Journal Paediatric, 2004; 71: 1003-1005

Ramde-Tiendrebeogo A, Tibiri A, Hilou A, Lomp OM, Millogo-Kone H, Nacoulma OG, Guissou IP. Antioxidative and antibacterial activities of phenolic compounds from Ficus sur Forssk. and Ficus sycomorus L. (Moraceae): Potential for sickle cell disease treatment in Burkina Faso. Int. J. Biol. Chem. Sci. 2012; 6(1):328-336.

Robert KM, Daryl KG, Peter AM, Victor WR. Harper's Illustrated Biochemistry. In Benders and Mayes Vitamins and Minerals, Lange Medical Books/McGraw-Hill, Medical Publishing Division, New York, 2003; 496
Sarker SD, Nahar L. Chemistry for Pharmacy Students General, Organic and Natural Product Chemistry. Indian Journal of Physiology and Pharmacology, 2007; 283-359.

Saxena M, Saxena J, Pradhan A. Flavonoids and Phenolic acids as antioxidants in plants and human health, Int. J. Pharm. Sci. Rev. Res., 2012; 16(2),: 130-134

Saxena M, Saxena J, Nema R, Singh D, Gupta, A. Phytochemistry of Medicinal Plants. Journal of Pharmacognosy and Phytochemistry Center for Microbiology and Bio-Technology Research and Training, Bhopal, India. 2013; 8192 (1): 168-182.

Sczkowski CP, Kalinowska M, Wojciechowski Z. The 3-Oglucosylation of steroidal saponins and alkaloids in eggplant (Solanum melongena); evidence for two separate glycosyl transferences, Phytochemistry, 1998; 48: 1151-1159.

Selvendran RR. The plant cell wall as a source of dietary fiber: chemistry and structure. American Journal of Clinical Nutrition, 1984; 39 : 320-337.

Sena LP, Vanderjadt JJ, Rivera C, Tsin ATC, Muhammadu I, Mahamadu, O, Milson M, Pastosyn A, Glew RH. Analysis of nutritional component of eight famine foods of Republic of Niger. Plant Food Human Nutrition, 1998; 52: 17 - 30

Siddhuraju P, Vijayakumari K, Janardhanam K. (1996): Chemical composition and protein quality of the little known legumes, velvet beans (Mucana Pruriens); Journal of Agriculture and Food Chemistry, 44: 2636 - 2641.

Thomas RA, Krishnakumari S. Proximate analysis and mineral composition of Myristica fragrans seeds Journal of Pharmacognosy and Phytochemistry, 2015; 3(6): 39-42

Thompson HC, Kelly WC. Vegetable Crops. $5^{\text {th }}$ Ed. New Delhi: Mac Graw Hill Publishing Company Ltd, 1990; 120-125.

Umeokoli BO, Onyegbule FA, Gugu TH, Igboeme SO. Evaluation of the erythropoietic and anti-sickling properties of Ficus capensis leaf extract in the treatment of anaemia. Planta Medica, 2013; 79 -PE29.

Uzoekwe NM, Mohammed JJ. Phytochemical, proximate and mineral contents of leaves and bark of Ficus capensis. Journal of Applied Science and Environmental Management, 2015; 8(4): 125 - 129.

Wangensteen H, Samuelsen AB, Malterud KE. Antioxidant activity in extracts from coriander. Food Chemistry, 2004; 88: 293-297.

Wills R, McGlasson B, Graham D, Joyce D. Postharvest: An Introduction to the physiology and handling of fruit, vegetables and ornamentals. Wallingford: CAB International, 1998; 262

World Health Organisation (WHO): Traditional Medicine Strategy. Geneva; 2014; 10(6): 15 - 20.

\section{How to cite this article:}

Achi NK, Onyeabo C, Ekeleme-Egedigwe CA, Onyeanula JC. Phytochemical, Proximate Analysis, Vitamin and Mineral Composition of Aqueous Extract of Ficus capensis leaves in South Eastern Nigeria. J App Pharm Sci, 2017; 7 (03): 117-122. 